\title{
Homocysteine and Cardiovascular Risk Factors in Overweight or Obese Children and Adolescents
}

\author{
Adriana Amorim de Farias Leal1, Mônica Oliveira da Silva Simões², \\ Alessandra Teixeira², Carla Campos Muniz Medeiros ${ }^{3}$, \\ Ástrid Camêlo Palmeira ${ }^{1}$, Gabriella Menezes Almeida de Castro4, \\ Mayara Larrys Gomes de Assis ${ }^{4}$, Maísa Soares de Oliveira ${ }^{4}$ \\ ${ }^{1}$ Graduate Program in Public Health, State University of Paraiba, Campina Grande, Brazil \\ ${ }^{2}$ Department of Pharmacy, State University of Paraiba, Campina Grande, Brazil \\ ${ }^{3}$ Department of Nursing, State University of Paraiba, Campina Grande, Brazil \\ ${ }^{4}$ Scientific Initiation Program, State University of Paraiba, Campina Grande, Brazil \\ Email: adriana-aafl@uol.com.br
}

Received 14 January 2015; accepted 12 March 2015; published 19 March 2015

Copyright (C) 2015 by authors and Scientific Research Publishing Inc.

This work is licensed under the Creative Commons Attribution International License (CC BY). http://creativecommons.org/licenses/by/4.0/

(c) (i) Open Access

\section{Abstract}

Introduction: Among the extrinsic factors, homocysteine (Hy) stands out, which is an intermediate amino acid of the intracellular metabolism of methionine involved in the process of cellular oxidation, which promotes the installation of atheromatous plaques and, therefore, is considered as an emerging cardiovascular risk factor. Objective: To evaluate the plasma homocysteine levels (Hy) in overweight or obese children and adolescents and their relation with cardiovascular risk factors. Methods: A cross-sectional study was conducted from July 2011 to May 2012 with overweight or obesity children and adolescents aged 2 to 18 years followed at the Center for Childhood Obesity (IOC), Campina Grande-PB. A structured form was used to record demographic, socioeconomic and clinics variables and the patients underwent laboratory tests to define their lipid and glucose profiles and measurement of plasma Hy levels. Results: The study evaluated a total of 165 children and adolescents with mean age of $12.5( \pm 2.5)$ years; the majority were female $(57.0 \%)$. Regarding the lipid profile, there was more individuals with low HDL cholesterol (88.5\%). Plasma Hy levels were high in $24.2 \%$ of the sample. The mean Hy levels ranged from 4.3 to $18.9 \mu \mathrm{mol} / \mathrm{L}$, being higher in males, obese adolescents and also in patients with high insulin levels and resistance. Conclusions: The results shown in this study emphasize the importance of detecting and controlling the plasma Hy levels as an independent cardiovascular risk factor, and the need for further studies to evaluate the clinical and biological factors related to alterations in its metabolism. 


\section{Keywords}

\section{Homocysteine, Cardiovascular Diseases, Child, Adolescent, Obesity}

\section{Introduction}

A significant increase in overweight and obesity among children and adolescents has been observed in developed and developing countries. In this context, overweight is an important risk marker for various diseases, particularly cardiovascular diseases (CVD) [1].

The etiogeny of CVD is associated with some risk factors that can be classified into two groups: intrinsic, or not susceptible to modification (age, sex, heredity) and extrinsic factors, or those that can be modified (dyslipidemia, diet, smoking, physical inactivity) [2].

Among the extrinsic factors, homocysteine (Hy) stands out, which is an intermediate amino acid of the intracellular metabolism of methionine involved in the process of cellular oxidation, which promotes the installation of atheromatous plaques and, therefore, is considered as an emerging cardiovascular risk factor [3].

Plasma Hy levels can be determined by genetic, biological, nutritional, hormonal and lifestyle factors [4]. Therefore, it is essential to investigate possible factors that are directly relate to the Hy concentrations such as enzyme deficit, low consumption of folate and vitamin B12, age, being male, high alcohol consumption and estradiol levels [5].

Considering, therefore, that the atherosclerotic process begins long before clinical aspects are detected, the cardiovascular risk factors, traditional or not, arise mainly with excess weight and the fatty streaks are observed even in childhood, is appropriate deepen the knowledge about childhood obesity and cardiovascular disease through research of its risk factors, such as Hy, especially since this intermediate of protein metabolism is involved in the understanding of vascular obstruction caused by atherosclerotic plaques, and therefore, necessary studies to identify factors associated with hyperhomocysteinemia [6].

Given the above, the aim of this study was to evaluate plasma Hy levels in overweight or obese children and adolescents and their relationship with cardiovascular risk factors.

\section{Methodology}

A cross-sectional study with quantitative approach was conducted, with data being collected from July 2011 to May 2012 with patients followed at the Center for Childhood Obesity (IOC), located at the "Elpídeo de Almeida" Institute of Health in Campina Grande-PB. A cross-sectional studies are viewing the status of a population in a given moment, as snapshots of reality. Describe the situation in a given time and for this reason often are classified wrongly as descriptive, as in reality, these studies allow the first time analysis of an association. The quantitative analysis of the studies, in turn, refers to submission of survey data numerically, classified and analyzed using statistical techniques.

This study is part of a broader project entitled "Cardiovascular and type-2 diabetes risk in obese children and adolescents with metabolic syndrome: a longitudinal study", approved by the Ethics Committee of the State University of Paraíba, under CAAE No. 0256.0.133.000-11.

The convenience sample was composed of overweight/obese children and adolescents aged from 2 and 18 years. In this period, 200 children and adolescents were followed at the IOC, of whom 26 did not accept performing blood collection; five were excluded as they were older than 19 years and four for having normal nutritional status, totaling 165 individuals.

Nutritional status was determined by calculating the body mass index (BMI). Patients with from $85^{\text {th }}$ to $95^{\text {th }}$ percentiles were classified as overweight and as obese those with $\geq 95^{\text {th }}$ percentile, defined as recommended by the Centers for Disease Control and Prevention [7]. Children, adolescents and their mothers were weighed on calibrated scales with accuracy of $0.1 \mathrm{~kg}$. Height was measured in rigid stadiometer with accuracy of $0.01 \mathrm{~cm}$. To assess maternal nutritional status, the criteria proposed by the World Health Organization-WHO were used [8].

Regarding family history of CVD (Systemic hypertension, type-2 diabetes, hypercholesterolemia, hypertriglyceridemia, acute myocardial infarction and stroke), the study considered the report of at least one of these 
events in first-degree relatives: parents, grandparents, aunts and uncles.

Waist circumference was measured at the midpoint between the lateral iliac crest and the lower edge of the last rib during expiration. Values above the $90^{\text {th }}$ percentile for age and sex were considered high, according to criteria proposed by the International Diabetes Federation [9], observing the upper limit of $88 \mathrm{~cm}$ for girls and $102 \mathrm{~cm}$ for boys, according to the National Cholesterol Education Program/Adult Treatment Panel III.

Blood pressure was measured three times by auscultation, with interval of 2 minutes, considering the average of the last two measures. The criteria for the diagnosis of high blood pressure followed the VI Brazilian Guidelines on Hypertension [10]. For individuals up to 17 years of age, those with systolic and/or diastolic blood pressure greater than or equal to the $90^{\text {th }}$ percentile have been diagnosed with high blood pressure. For individuals older than 17 years, those with systolic blood pressure greater than or equal to $140 \mathrm{mmHg}$ and diastolic blood pressure greater than or equal to $90 \mathrm{mmHg}$ have been diagnosed with high blood pressure.

For biochemical analyzes, patients were submitted to a 12-hour fasting period before blood collection of 10 $\mathrm{mL}$. Triglycerides, total cholesterol and fractions and glucose levels were measured by the enzymatic colorimetric method. The cutoff points for unsatisfactory lipid levels were determined by the I Guideline for Prevention of Atherosclerosis in Childhood and Adolescence [11]. Hyperglycemia was determined from values equal to or greater than $100 \mathrm{mg} / \mathrm{dL}$, in accordance with criteria established by the American Diabetes Association [12]. Regarding insulin, measured by chemiluminescence, values greater than or equal to $15 \mu \mathrm{UI} / \mathrm{mL}$ were considered high (61). The insulin resistance level (HOMA-IR) was calculated as the product of insulin levels by blood glucose and dividing the result by 22.5 , with HOMA-IR $\geq 2.5$ being considered as cutoff [13].

The method used for Hy determination was the High Performance Liquid Chromatography (HPLC) and the reference values adopted for this study were those suggested by Refsum et al. [14], which established values higher than or equal to $10 \mathrm{mmol} / \mathrm{L}$ as high for individuals under 14 years of age, and values higher than or equal to $15 \mathrm{mmol} / \mathrm{L}$ as high for those aged 15 years or more.

Biochemical determinations were performed at the Clinical Laboratory of the State University of Paraíba, except for insulin dosages and Hy, which were performed at another laboratory, with funding by research incentives, certified by the Brazilian Society of Clinical Analyses.

Descriptive statistical analysis was carried out by mean, standard deviation and frequencies, and data were analyzed using the SPSS software, version 17.0. For the association between Hy and the other cardiovascular risk factors, the Chi-square test was used and to compare means, analysis of variance was used. The significance level adopted was 5.

\section{Results}

Of the total of 165 children and adolescents evaluated, the mean age was $12.5( \pm 3.5)$ for the total sample, and $8.9( \pm 2.1)$ for the children and $14.3( \pm 4.1)$ years for the adolescents. Most were female $(57.0 \%)$, adolescents (75.2\%) and non-white skin color (63.6\%). Demographic and socioeconomic variables are described in Table 1.

Table 2 describes the variable family history. The majority of patients showed three or more antecedents (78.8\%), and the most frequent was hypertension (84.8\%).

In relation to the other clinical variables, $83.0 \%$ of the sample showed nutritional status of obesity. Regarding the lipid profile, there is a greater number of individuals with low HDL cholesterol (88.5\%). Plasma Hy levels were high in $25.0 \%$ of the sample.

Table 3 shows the frequency and odds ratios with respective confidence intervals (CI 95\%) for cardiovascular risk factors according to the plasma Hy levels.

The mean Hy value was $9.2 \mu \mathrm{mol} / \mathrm{L}( \pm 2.9)$, with minimum value of $4.3 \mu \mathrm{mol} / \mathrm{L}$ and maximum value of 18.9 $\mu \mathrm{mol} / \mathrm{L}$. When compared by cardiovascular risk factor, it was found that the means were significantly higher in the following groups: males, adolescents, patients with obesity, higher insulin levels and presence of insulin resistance (Table 4). There was statistical significance between Hy and age, sex, and insulin resistance.

\section{Discussion}

The fact that CVD may originate in childhood and adolescence leads to the need for a wide investigation of cardiovascular risk factors in this phase, aiming at early intervention and thus reducing morbidity and mortality in adulthood [15].

According to Bereson et al. [16], cardiovascular risk is directly proportional to the obesity degree. The IOC 
Table 1. Percentage distribution of demographic and socioeconomic data, according to the sex of overweight/obese children and adolescents followed at the IOC $(n=165)$, Campina Grande, 2011-2012.

\begin{tabular}{|c|c|c|}
\hline \multirow{3}{*}{ Variables } & \multicolumn{2}{|c|}{ Sex } \\
\hline & Male & Female \\
\hline & n (\%) & n (\%) \\
\hline \multicolumn{3}{|l|}{ Age group } \\
\hline Child (2 to 9 years) & $21(51.2)$ & $20(48.8)$ \\
\hline Adolescent (10 to 19 incomplete years) & $50(40.3)$ & 74 (59.7) \\
\hline \multicolumn{3}{|l|}{ Nutritional Status of Children/Adolescents } \\
\hline Overweight $(85 \leq$ pBMI $<95)$ & $08(28.6)$ & $20(71.4)$ \\
\hline Obesity $(\mathrm{pBMI} \geq 95)$ & $63(46.0)$ & $74(54.0)$ \\
\hline \multicolumn{3}{|l|}{ Skin color } \\
\hline White & $25(41.7)$ & 35 (58.3) \\
\hline Non-white & $46(43.8)$ & $59(56.2)$ \\
\hline \multicolumn{3}{|l|}{ Type of school } \\
\hline Private & $34(41.5)$ & $48(58.5)$ \\
\hline Public & $36(44.4)$ & $45(55.6)$ \\
\hline Not enrolled & $01(50.0)$ & $01(50.0)$ \\
\hline \multicolumn{3}{|l|}{ Total family income } \\
\hline$\leq$ two MW & 38 (46.9) & $43(53.1)$ \\
\hline$>$ two MW & $33(39.3)$ & $51(60.7)$ \\
\hline \multicolumn{3}{|l|}{ Number of household members } \\
\hline $2-5$ & $61(42.4)$ & $83(57.6)$ \\
\hline 6 or more & $10(47.6)$ & $11(52.4)$ \\
\hline \multicolumn{3}{|l|}{ Maternal Nutritional Status } \\
\hline Underweight & $00(0.0)$ & $01(100.0)$ \\
\hline Normal weight & $10(32.3)$ & $21(67.7)$ \\
\hline Overweight & $24(44.4)$ & $30(55.6)$ \\
\hline Obesity & $37(46.8)$ & $42(53.2)$ \\
\hline \multicolumn{3}{|l|}{ Maternal schooling } \\
\hline$\leq 8$ years of study & $17(37.0)$ & $29(63.0)$ \\
\hline$\geq 9$ years of study & $54(45.4)$ & $65(54.6)$ \\
\hline
\end{tabular}

Table 2. Percentage distribution of family history of overweight/obese children and adolescents followed at the IOC $(n=165)$, in relation to the presence, number and type of antecedent, Campina Grande, 2011-2012.

$\begin{array}{cc}\text { Variables } & \mathbf{n ~ ( \% )} \\ \text { Presence of antecedents } & \\ \text { Yes } & 162(98.2) \\ \text { No } & 03(1.8) \\ \text { Number of antecedents } & \\ 1 \text { - } 2 & 35(821.2) \\ 3 \text { or more } & 130(78.8) \\ \text { Type of antecedent } & 140(84.8) \\ \text { Systemic Hypertension } & 122(73.9) \\ \text { Obesity } & 109(66.1) \\ \text { Type-2 Diabetes Mellitus } & 86(52.1) \\ \text { Hypercholesterolemia } & 56(33.9) \\ \text { Acute Myocardial Infarction } & 53(32.1) \\ \text { Hypertriglyceridemia } & 45(27.3) \\ \text { Stroke } & \end{array}$


Table 3. Frequency and odds ratios with respective confidence intervals (CI 95\%) for cardiovascular risk factors according to the plasma Hy levels of overweight/obese children and adolescents followed at IOC ( $\mathrm{n}=165)$, Campina Grande, 20112012.

\begin{tabular}{|c|c|c|c|c|c|}
\hline \multirow{3}{*}{ Variables } & \multirow{3}{*}{$\begin{array}{c}\text { Total } \\
(\mathrm{n}=165)\end{array}$} & \multicolumn{2}{|c|}{ Hy levels } & \multirow{3}{*}{ OR (CI 95\%) } & \multirow{3}{*}{$p^{*}$} \\
\hline & & High Hy $(n=40)$ & Normal Hy $(n=125)$ & & \\
\hline & & n (\%) & n (\%) & & \\
\hline \multicolumn{6}{|l|}{ Waist circumference } \\
\hline Increased ( $>90^{\text {th }}$ percentile) & $121(73.3)$ & $28(23.1)$ & 93 (76.9) & \multirow{2}{*}{$\begin{array}{c}0.803 \\
(0.366-1.763)\end{array}$} & \multirow{2}{*}{0.584} \\
\hline Normal & $44(26.7)$ & $12(27.3)$ & $32(72.7)$ & & \\
\hline \multicolumn{6}{|l|}{ Systolic Blood Pressure } \\
\hline High ( $\geq 90^{\text {th }}$ percentile) & $24(14.5)$ & $05(20.8)$ & $19(79.2)$ & \multirow{2}{*}{$\begin{array}{c}0.797 \\
(0.277-2.293)\end{array}$} & \multirow{2}{*}{0.448} \\
\hline Normal & $141(85.5)$ & $35(24.8)$ & $106(75.2)$ & & \\
\hline \multicolumn{6}{|l|}{ Diastolic Blood Pressure } \\
\hline High ( $\geq 90^{\text {th }}$ percentile) & $46(27.9)$ & 09 (19.6) & $37(80.4)$ & \multirow{2}{*}{$\begin{array}{c}0.690 \\
(0.299-1.592)\end{array}$} & \multirow{2}{*}{0.503} \\
\hline Normal & $119(72.1)$ & $31(26.1)$ & 88 (73.9) & & \\
\hline \multicolumn{6}{|l|}{ Total Cholesterol } \\
\hline High ( $\geq 150$ mg/dL) & $101(61.2)$ & $19(18.8)$ & $82(81.2)$ & \multirow{2}{*}{$\begin{array}{c}0.474 \\
(0.230-0.977)\end{array}$} & \multirow{2}{*}{0.041} \\
\hline Normal & $64(38.8)$ & $21(32.8)$ & $43(67.2)$ & & \\
\hline \multicolumn{6}{|l|}{ LDL Cholesterol } \\
\hline High $(\geq 100$ mg/dL) & $83(50.3)$ & $18(21.7)$ & $65(78.3)$ & \multirow{2}{*}{$\begin{array}{c}0.717 \\
(0.350-1.470)\end{array}$} & \multirow{2}{*}{0.363} \\
\hline Normal & 79 (49.7) & $22(27.8)$ & $57(72.2)$ & & \\
\hline \multicolumn{6}{|l|}{ HDL Cholesterol } \\
\hline Low (<45 mg/dL) & $146(88.5)$ & $38(95.0)$ & $108(86.4)$ & \multirow{2}{*}{$\begin{array}{c}2.991 \\
(0.660-13.553)\end{array}$} & \multirow{2}{*}{0.111} \\
\hline Normal & $19(11.5)$ & $02(5.0)$ & $17(13.6)$ & & \\
\hline \multicolumn{6}{|l|}{ Triglycerides } \\
\hline High ( $\geq 100$ mg/dL) & $104(63.0)$ & $22(21.2)$ & $82(78.8)$ & \multirow{2}{*}{$\begin{array}{c}0.641 \\
(0.311-1.322)\end{array}$} & \multirow{2}{*}{0.227} \\
\hline Normal & $61(37.0)$ & $18(29.5)$ & $43(70.5)$ & & \\
\hline \multicolumn{6}{|l|}{ Blood glucose } \\
\hline High ( $\geq 100$ mg/dL) & 03 (1.9) & $01(33.3)$ & $02(66.7)$ & \multirow{2}{*}{$\begin{array}{c}1.577 \\
(0.139-17.864)\end{array}$} & \multirow{2}{*}{0.568} \\
\hline Normal & $162(98.1)$ & $39(24.1)$ & 123 (75.9) & & \\
\hline \multicolumn{6}{|l|}{ Insulin levels } \\
\hline $\operatorname{High}(\geq 15 \mu \mathrm{UI} / \mathrm{mL})$ & $40(25.0)$ & $12(30.0)$ & $28(70.0)$ & 1.485 & (230 \\
\hline Normal & $125(75.0)$ & $28(22.4)$ & 97 (77.6) & $(0.670-3.292)$ & 0.329 \\
\hline Insulin resistance & & & & & \\
\hline Present (HOMA $\geq 2.5$ ) & $56(33.9)$ & $16(28.6)$ & $40(71.4)$ & 1.417 & 0355 \\
\hline Absent & 109 (66.1) & $24(22.0)$ & $85(78.0)$ & $(0.679-2.957)$ & 0.332 \\
\hline
\end{tabular}

${ }^{*}$ Chi-square test. 
Table 4. Mean values, standard deviation and confidence interval of Hy levels according to the other cardiovascular risk factors of overweight/obese children and adolescents followed at the IOC ( $\mathrm{n}=165)$, Campina Grande, 2011-2012.

\begin{tabular}{|c|c|c|c|c|c|}
\hline \multirow{2}{*}{ Variables } & \multicolumn{2}{|c|}{ Homocysteíne $(\mu \mathrm{mol} / \mathrm{L})$} & \multirow{2}{*}{ Variables } & \multicolumn{2}{|c|}{ Homocysteíne $(\mu \mathrm{mol} / \mathrm{L})$} \\
\hline & Mean \pm SD (CI 95\%) & $p^{*}$ & & Mean \pm SD (CI 95\%) & $p^{*}$ \\
\hline Sex & & & Total Cholesterol & & \\
\hline Male & $9.9 \pm 3.4(9.1-10.7)$ & \multirow{2}{*}{0.005} & High & $9.0 \pm 2.7(8.5-9.5)$ & \multirow{2}{*}{0.310} \\
\hline Female & $8.7 \pm 2.3(8.2-9.1)$ & & Normal & $9.5 \pm 3.1(8.7-10.2)$ & \\
\hline Age & & & HDL Cholesterol & & \\
\hline Children & $8.4 \pm 1.9(7.8-9.0)$ & \multirow{2}{*}{0.036} & Low & $9.3 \pm 3.0(8.8-9.8)$ & \multirow{2}{*}{0.096} \\
\hline Adolescents & $9.5 \pm 3.1(8.9-10.0)$ & & Normal & $8.1 \pm 1.3(7.5-8.8)$ & \\
\hline Nutritional status & & & LDL Cholesterol & & \\
\hline Overweight & $9.0 \pm 3.1(7.8-10.3)$ & \multirow{2}{*}{0.757} & High & $9.1 \pm 2.8(8.5-9.8)$ & \multirow{2}{*}{0.649} \\
\hline Obesity & $9.2 \pm 2.8(8.7-9.7)$ & & Normal & $9.3 \pm 2.9(8.8-10.0)$ & \\
\hline Waist circumference & & & Blood glucose levels & & \\
\hline Increased & $9.1 \pm 2.7(8.6-9.6)$ & \multirow{2}{*}{0.322} & High & $8.5 \pm 1.4(5.1-11.9)$ & \multirow{2}{*}{0.671} \\
\hline Normal & $9.6 \pm 3.2(8.6-10.6)$ & & Normal & $9.2 \pm 2.9(8.8-9.7)$ & \\
\hline Systolic blood pressure & & & Insulin levels & & \\
\hline High & $8.5 \pm 2.0(7.6-9.3)$ & \multirow{2}{*}{0.182} & High & $10.0 \pm 3.2(8.8-10.9)$ & \multirow{2}{*}{0.081} \\
\hline Normal & $9.3 \pm 3.0(8.8-9.8)$ & & Normal & $9.0 \pm 2.7(8.5-9.4)$ & \\
\hline Diastolic blood pressure & & & Insulin resistance & & \\
\hline High & $9.0 \pm 2.8(8.1-9.8)$ & \multirow{2}{*}{0.504} & Present & $10.0 \pm 3.5(9.1-10.9)$ & \multirow{2}{*}{0.011} \\
\hline Normal & $9.3 \pm 2.9(8.8-9.8)$ & & Absent & $8.8 \pm 2.4(8.3-9.3)$ & \\
\hline \multicolumn{6}{|l|}{ Triglycerides } \\
\hline High & $9.1 \pm 3.1(8.5-9.7)$ & \multirow{2}{*}{0.437} & & & \\
\hline Normal & $9.4 \pm 2.5(8.8-10.1)$ & & & & \\
\hline
\end{tabular}

*Analysis of variance.

sample showed a common characteristic: excess weight. In Brazil, the process of nutritional transition observed in recent decades indicates increased overweight and obesity prevalence in the general population. Leal et al. [17] conducted a population-based study with children and adolescents from 5 to 19 years of age and found an overweight prevalence of $13.3 \%$ in the state of Pernambuco, $9.5 \%$ of overweight and $3.8 \%$ of obesity.

In relation to the maternal nutritional status, this study found that $24.1 \%$ of mothers were overweight, a fact that corroborates the results found by Silva, Baladan and Motta [18], who studied obese children and adolescents aged 7 - 12 years and their parents and found that the nutritional status of their mothers was significantly changed (29.9\% overweight).

In a study by Strufaldi, Silva and Puccini [19], from the 929 schoolchildren assessed, 328 (35.3\%) reported positive family history for CVD; of these, $20.0 \%$ had a history of early CVD, $17.3 \%$ of hypertension, $8.5 \%$ of obesity, 5.9\% of dyslipidemia, and 3.7\% of type-2 DM. In our study, however, there was a higher prevalence (97.7\%) of children and adolescents with reported family history, highlighting the occurrence of hypertension (82.2\%), and grandparents were the relatives most reported in these antecedents (93.6\%). Regarding the family history, there was a prevalence of three or more antecedents $(78.8 \%)$.

Studies indicate that systemic hypertension can start in childhood. In 2012, Rinaldi et al. [20] evaluated 903 children and adolescents from Botucatu (SP) with mean age of $9.3( \pm 2.5)$ years and found hypertension preva- 
lence of $2.9 \%$. Freitas et al. [21], in turn, assessed a sample of 184 adolescents, of which $9.8 \%$ showed high systolic blood pressure and $12.5 \%$ increased diastolic blood pressure. With similar frequencies and using the same cutoff points of these studies, $14.5 \%$ of the IOC sample showed high systolic blood pressure and $27.9 \%$ high diastolic blood pressure, showing a strong relationship between overweight and high blood pressure.

Obesity leads to changes in lipid metabolism. The WHO has reported that approximately $84.0 \%$ of adolescents live in developing countries such as Brazil, and that this percentage in relation to the other groups increased, but little importance has been given to the determination of the lipid profile in adolescence [22]. However, recent studies have claimed that hypertriglyceridemia associated with high LDL cholesterol levels increases by six times the risk of CVD, and that the development of atherosclerosis in obese adolescents is enhanced by increased plasma cholesterol levels. In addition, the oxidation of LDL cholesterol particles in the arterial walls is considered the main event for the development of atheromatous plaques [23].

Regarding the lipid profile in 2010, Araki, Barros and Santos [24] evaluated 297 children and adolescents and showed disturbing results in relation to HDL cholesterol levels, since $41.7 \%$ of the sample had low levels. In this study, however, using the same cutoff points, there was a greater frequency (88.5\%) of HDL cholesterol below the threshold used, which is a worrisome fact, since increased serum levels of this lipoprotein reduce cardiovascular risk due to reverse cholesterol transportation, removing it from the cells and transporting it to the liver for subsequent excretion [25].

In addition to the cardiovascular risk factors discussed above, high plasma Hy levels are an emerging risk factor for CVD (3). The pathogenesis of vascular injury determined by Hhy includes endothelial cell injury, growth of the smooth vascular muscle, increased platelet aggregation, increased LDL cholesterol oxidation with deposition on the vascular wall and direct activation of the coagulation cascade [26]. Thus, the plasma Hy levels may be influenced by biological changes such as sex and age, and other clinical factors such as dyslipidemia [27]. In this sense, the literature shows the relationship between increased synthesis of cholesterol and elevated Hy levels through studies in cultured liver cells, also showing the increased expression of the Hydroxy-MethylGlutaryl-Coenzyme A reductase enzyme, responsible for the formation of cholesterol [28] [29].

Regarding sex, Almeida et al. [30] showed that the Hy concentrations tended to be higher in men than in women, because women have the protective effect of estrogen. With advancing age, these levels also increase, remaining as a risk factor for coronary heart disease, aggravated by the deficiency of vitamins. The study by Kerr et al. [31] with children and adolescents between 4 and 18 years of age found that the Hy concentrations gradually increased with increasing age and were higher in boys $(6.3 \mathrm{mmol} / \mathrm{L})$ than in girls $(6.2 \mathrm{mmol} / \mathrm{L})$. Similarly, Akanji, Thalib and Al-Isa [32] studied adolescents from 10 to 19 years of age and concluded that there is a direct relationship between increasing age and plasma Hy levels and that boys showed total average Hy levels significantly higher $(8.25 \mu \mathrm{mol} / \mathrm{L})$.

The IOC sample studied has diagnosis of overweight or obesity, which is a characteristic that contributes to the development of atherosclerosis. It is believed that factors related to lifestyle may interfere with elevated plasma Hy levels. Accordingly, the prevalence of overweight can negatively influence the plasma Hy concentrations, considering that obesity is characterized by excessive consumption of high-calorie foods, poor of protein and vitamins [33]. Therefore, the average Hy value was higher in children or adolescents with diagnosis of obesity $(9.3 \mu \mathrm{mol} / \mathrm{L})$. In addition, the work by Brasileiro et al. [34], whose sample consisted of adolescents with and without excess weight, showed higher Hy levels in overweight individuals.

Regarding the glucose profile, the mean Hy value was higher in patients with elevated fasting insulin and / or insulin resistance. Studies have shown that elevated plasma insulin levels can lead to Hhe, possibly due to changes in enzymes involved in the Hy metabolism, especially cystathionine- $\beta$-synthase, involved in the transsulfuration pathway [35] [36].

Finally, is important to consider some limitations. The data presented are from a cross-sectional design, which does not require the composition of a control group for comparison, so it was not possible to assess the temporal sequence between exposure of interest on the biochemical factors studied. yet, because they are information provided from a convenience sample, the study did not allow the extrapolation of results and needed to conduct population surveys of this problem.

\section{Conclusion}

The mean plasma Hy concentrations are higher in males, adolescents and patients with insulin resistance, which 
is important when one considers that biological and clinical characteristics reduce the metabolism of this intermediate amino acid and that all these factors are associated with cardiovascular risk. Thus, these results can guide public health actions aimed to reduce, since childhood, the risk of developing CVD and expenses related to their treatment.

\section{Acknowledgements}

To the UEPB Scientific Initiation students who carefully played their role as researchers: Gabriella Menezes Almeida de Castro, Mayara Larrys Gomes de Assis, Maísa Soares de Oliveira, José de Alencar Fernandes Neto, Débora Larissa Rufino Alves and Nathaly de Medeiros Nóbrega Ramos. To the National Council for Scientific and Technological Development-CNPq for granting Master's scholarship to the first author and to the Incentive Program for Graduate Studies and Research_PROPESQ/UEPB for funding during implementation and data collection. To the members of the Center for Childhood Obesity for their multidisciplinary support.

\section{References}

[1] Lavrador, M.S.F., et al. (2011) Riscos Cardiovasculares em Adolescentes com Diferentes Graus de Obesidade. Arquivos Brasileiros de Cardiologia, 96, 205-211. http://dx.doi.org/10.1590/S0066-782X2010005000166

[2] Girotto, E., Andrade, S.M., Cabrera, A.S. and Ridão, E.G. (2009) Prevalência de fatores de risco para doenças cardiovasculares em hipertensos cadastrados em unidade de saúde da família. Maringá, 31, 77-82.

[3] Moura, M.S.B., Martins, M.C.C. and Souza Filho, M.D. (2011) Hiper-homocisteinemia como fator de risco cardiovascular. Com Scientiae Saúde, 10, 181-185.

[4] Kutilek, S., Nemec, V. and Bockayova, E. (2012) Níveis séricos elevados de homocisteína em pacientes pediátricos com fenômeno de Raynaud primário. Revista Brasileira de Reumatologia, 52, 128-130. http://dx.doi.org/10.1590/S0482-50042012000100014

[5] Amorim, K.S., Lopes, A.S. and Pereira, I.A. (2011) Impacto do exercício físico nos níveis de homocisteína, um fator de risco para aterosclerose: revisão sistemática. Revista Brasileira de Atividade Física \& Saúde, 16, 70-75.

[6] Villarreal, E., Forero, Y., Poveda, E., Baracaldo, C. and López, E. (2008) Marcadores de riesgo cardiovascular em escolares de cinco departamentos de la región oriental em Colombia. Biomédica, 28, 38-49. http://dx.doi.org/10.7705/biomedica.v28i1.107

[7] Centers of Disease Control and Prevention (CDC) (2000) Table for Calculated Body Mass Index Values for Selected Highs and Weights for Ages 2 to 20 Years. Developed by the National Center for Health Statistc in Collaboration with the National Center for Chronic Disease Prevention and Health Promotion. http://www.cdc.gov/growthcharts

[8] World Health Organization (1995) Physical Status: The Use and Interpretation of Anthropometry. World Health Organization, Geneva.

[9] International Diabetes Federation (IDF) (2007) The IDF Consensus Definition of Metabolic Syndrome in Children and Adolescents. http://www.idf.org/home/index.cfm?node=1429

[10] Sociedade Brasileira de Cardiologia (SBC) (2010) VI Diretrizes Brasileiras de Hipertensão. Arquivos Brasileiros de Cardiologia, 95, 1-51.

[11] Sociedade Brasileira de Cardiologia, SBC (2005) I Diretriz de Prevenção da Aterosclerose na Infância e na Adolescência. Arquivos Brasileiros de Cardiologia, 85, 1-36.

[12] American Diabetes Association (2009) Standards of Medical Care in Diabetes. Diabetes Care, 32, S13-S61.

[13] Madeira, I.R., Miranda Carvalho, C.N., Gazolla, F.M., de Matos, H.J., Borges, M.A. and Bordallo, M.A.N. (2008) Ponto de corte do índice Homeostatic Model Assessment for Insulin Resistance (HOMA-IR) avaliado pela curva Receiver Operating Characteristic (ROC) na detecção de síndrome metabólica em crianças pré-púberes com excesso de peso. Arquivos Brasileiros de Endocrinologia \& Metabologia, 52, 1466-1473. http://dx.doi.org/10.1590/S0004-27302008000900010

[14] Refsum, H., Smith, A.D., Ueland, P.M., Nexo, E., Clarke, R., Mc Partlin, J., et al. (2004) Facts and Recommendations about Total Homocysteine Determinations: An Expert Opinion. Clinical Chemistry, 50, 3-32. http://dx.doi.org/10.1373/clinchem.2003.021634

[15] Santos, M.G., Pegoraro, M., Sandrini, F. and César, E. (2008) Fatores de risco no desenvolvimento da aterosclerose na infância e adolescência. Arquivos Brasileiros de Cardiologia, 90, 276-283. http://dx.doi.org/10.1590/S0066-782X2008000400012

[16] Bereson, G.S., Srinivasan, S.R., Bao, W., Newman, W.P., Tracy, R.E. and Wattigney, W.A. (1998) Association between Multiple Cardiovascular Risk Factor and Atherosclerosis in Children and Young Adults. The New England 
Journal of Medicine, 338, 1650-1656. http://dx.doi.org/10.1056/NEJM199806043382302

[17] Leal, V.S., de Lira, P.I.C., Oliveira, J.S., de Menezes, R.C.E., de Souza Sequeira, L.A., de Arruda Neto, M.A., et al. (2012) Excesso de peso em crianças e adolescentes no Estado de Pernambuco, Brasil: Prevalência e determinantes. Cadernos de Saúde Pública, 28, 1175-1182. http://dx.doi.org/10.1590/S0102-311X2012000600016

[18] Silva, A.P.S., Baladan, G. and Motta, M.E.F. (2005) Prevalência de sobrepeso e obesidade em crianças e adolescentes de diferentes condições socioeconômicas. Revista Brasileira de Saúde Materno Infantil, 5, 53-59. http://dx.doi.org/10.1590/S1519-38292005000100007

[19] Louzada, S.M.W., Silva, E.M.K. and Puccini, R.F. (2011) Sobrepeso e obesidade em escolares pré-púberes: Associação com baixo peso ao nascer e antecedentes familiares para doença cardiovascular. Embu região metropolitana de São Paulo, 2006. Ciência Saúde Coletiva, 16, 4465-4472.

[20] Rinaldi, A.E.M., Nogueira, P.C.K., Riyuzo, M.C., Olbrich-Neto, J., Gabriel, G.F.C.P., Macedo, C.S. and Burini, R.C. (2012) Prevalência de pressão arterial elevada em crianças e adolescentes do ensino fundamental. The Revista Paulista de Pediatria, 30, 79-86. http://dx.doi.org/10.1590/S0103-05822012000100012

[21] Freitas, D., Rodrigues, C.S., Yagui, C.M., Carvalho, R.S.T. and Marchi-Alves, L.M. (2012) Fatores de risco para hipertensão arterial entre estudantes do ensino médio. Acta Paulista de Enfermagem, 25, 430-434. http://dx.doi.org/10.1590/S0103-21002012000300017

[22] Mendes, M.J.F.L., Alves, J.G.B., Alves, A.V., Siqueira, P.P. and Freire, E.F.C. (2006) Associação dos fatores de risco para doenças cardiovasculares em adolescentes e seus pais. Revista Brasileira de Saúde Materno Infantil, 6, 549-554.

[23] Franca, E. and Alves, J.G.B. (2006) Dislipidemia entre crianças e adolescentes de Pernambuco. Arquivos Brasileiros de Cardiologia, 87, 722-727. http://dx.doi.org/10.1590/S0066-782X2006001900007

[24] Araki, M.V.R., Barros, C. and Santos, E.G. (2010) Análise do perfil lipídico de crianças e adolescentes ndo estado de Sergipe. Scientia Plena, 6, 1-6.

[25] Gothelf, S.J. and Jubany, L.L. (2007) Antropometría y lípidos séricos en niños y adolescentes obesos de la ciudad de Salta, 2006. Archivos Argentinos de Pediatría, 105, 411-417.

[26] Vannucchi, H. and Melo, S.S. (2009) Hiper-homocisteinemia e risco cardiometabólico. Arquivos Brasileiros de Endocrinologia \& Metabologia, 53, 540-549. http://dx.doi.org/10.1590/S0004-27302009000500007

[27] Cardoso, I.L. (2009) Homocisteína e a Doença Cardiovascular. Revista da Faculdade de Ciências da Saúde, 6, 198206.

[28] Amorim, F.G., de Rezende, L.C.D., Coitinho, L.B., de Freitas, J.V., Scherr, J.A. and Dettogni, R.S. (2011) Bioquímica clínica da aterosclerose provocada por hiper-homocisteinemia. Revista Eletrônica de Farmácia, 8, 36-59. http://dx.doi.org/10.5216/ref.v8i1.13812

[29] Guerra, M. and Hernández-Rodríguez, P. (2011) Homocisteína, implicaciones en riesgo cardiovascular. Revista Cienciactual, 1, 41-57.

[30] Almeida, L.C., Tomita, L.Y., D’Almeida, V. and Cardoso, M.A. (2008) Preditores sócio-demográficos, de estilo de vida e gineco-obstétricos das concentrações séricas ou plasmáticas de homocisteína, ácido fólico e vitaminas B12 e B6 em mulheres de baixa renda de São Paulo, Brasil. Cadernos de Saúde Pública, 24, 587-596. http://dx.doi.org/10.1590/S0102-311X2008000300012

[31] Kerr, M.A., Livingstone, B., Bates, C.J., Bradbury, I., Scott, J.M., Ward, M., et al. (2009) Folate, Related B Vitamins, and Homocysteine in Childhood and Adolescence: Potential Implications for Disease Risk in Later Life. Pediatrics, 123, 627-635. http://dx.doi.org/10.1542/peds.2008-1049

[32] Akanji, A.O., Thalib, L. and Al-Isa, A.N. (2010) Folate, Vitamin B12 and Total Homocysteine Levels in Arab Adolescent Subjects: Reference Ranges and Potential Determinants. Nutrition, Metabolism \& Cardiovascular Diseases, 20, $1-7$.

[33] Pinto, W.J. (2009) Homocisteína e risco cardiovascular. Revista de Ciências Médicas, 18, 259-268.

[34] Brasileiro, R.S., Escrivão, M.A.M.S., Taddei, J.A.A.C., Almeida, V.D. and Ancona-Lopez, F. (2005) Plasma Total Homocysteine Overweight and Non-Overweight Adolescents: A Case-Control Study. Nutricion Hospitalaria, 20, 313319.

[35] Paixão, J.M. (2011) Importância dos polimorfismos do metabolismo da Hemocisteína na susceptibilidade para a Diabetes Mellitus do tipo II (Dissertação). Tese de mestrado, Universidade de Lisboa, Faculdade de Ciências, Biologia (Biologia Humana e Ambiente).

[36] Cerquera, J.M.C., Costa, L.O.B.F., Nogueira, A.A.V., Silva, D.C.C., Torres, D.O.C. and Santos, A.C.O. (2010) Homocisteinemia em mulheres com síndrome dos ovários policísticos. Revista Brasileira de Ginecologia e Obstetrícia, 32, 126-132. http://dx.doi.org/10.1590/S0100-72032010000300005 